\title{
Lean Six Sigma in Jordanian Organizations
}

Submitted 11/03/20, $1^{\text {st }}$ revision $14 / 04 / 20,2^{\text {nd }}$ revision $27 / 05 / 20$, accepted 30/07/20

\author{
Khalid Mohummed Alomari ${ }^{1}$, Ahmad Moh'd Mansour ${ }^{2}$, Ahmad Ali Almohtaseb ${ }^{3}$, \\ Ali A. Salah ${ }^{4}$, Khaled (M.K) Ismail Alshaketheep ${ }^{5}$, Ahmad Abdullah abu Jray ${ }^{6}$
}

\begin{abstract}
:
Purpose: The manufacturing sector with Lean Six Sigma is constantly improving (CI). CI is helping the organization to achieve and develop its efficiency and operational excellence. Synergizing all methods thus, helps to achieve better efficiency than using one method alone. This results in better quality. Thus, many companies have taken LSS for CI. Yet, inside LSS areas, there are clear restrictions. Very few think about the LSS cap.

Design/Methodology/Approach: Data were gathered by questionnaires from 264 managers. The comparison analysis was performed and then a multiple regression model was used to test the hypotheses following confirmation of normality, validity and reliability.

Findings: The results indicate that the Jordanian manufacturing organizations rely on high adoption of Lean Six Sigma variables; the lean six sigma variables, with absence of unused expertise and transport, have good relationships with business efficiency. All the reasons Lean Six Sigma affect business performance, except for industry in Jordan, which has expanded results from one industry and/or country to other industry and/or nations. Manufacturing companies can improve their business performance, other manufacturing industries can also be introduced.

Practical Implications: All organizations aim to reduce the amount of waste that contributes to the protection of natural resources and to social responsibility of companies.

Originality Value: The research helps experts and judges to recognize new processes and methods of development that add value and promote competitive advantages.
\end{abstract}

Keywords: Lean Six Sigma, default, over production, transportation, inventory, waiting time.

JEL codes: L11, L15.

Paper type: Research paper.

\footnotetext{
${ }^{1}$ Assistant Professor, Business Department, College of Business and Economics. Al-Hussein Bin Talal University khaled@ahu.edu.jo;

${ }^{2}$ Assistant Professor, Business Department, Faculty of Business

Al-Balqa Applied Universityahmadmansour@bau.edu.jo

${ }^{3}$ Assistant Professor, Business Department, College of Business and Economics

Al-Hussein Bin Talal University Muhtaseb_ma@ahu.edu.jo;

${ }^{4}$ Associate Professor, Business Department, College of Business and Economics

Al-Hussein Bin Talal University aliataslah@yahoo.com

${ }^{5}$ Research scholar, E-mail: k.alshikh@gmail.com;

${ }^{6}$ Research scholar, a.aljery@ahu.edu.jo;
} 


\section{Introduction}

Throughout different organisations across the world, the Lean Six Sigma (LSS) is the new constantly improving strategy (CI) (Wang and Chen 2010). The Lean Six SIGMA and SIGMA are the two effective CI methods (Vinodh et al., 2012). The goal would be to raise efficiency and minimize manufacturing costs within an enterprise (Chen and Lyu, 2009) and optimize shareholder value by quality enhancement (Antony et al., 2003). LSS is an effective process control and reliable technology. Price has been a common topic for a long time. Markets have changed dramatically in recent decades due to globalization and rapid technological growth, leading to low-cost competition and increased consumer awareness. As a consequence, different methods and procedures describing quality have been developed, from Quality Inspection (QI) to Quality Control (QA) and Complete Quality Management (TQM), all established by Japanese companies. Since American companies were unable to compete on the global market, American companies have introduced good management of IBM standard. Toyota was in reality the first organization talked about efficiency, development, low cost and consumer maximization. While several Western organisations use LSS, in Middle East countries such as Saudi Arabia it is still embraced and growing. Empirical work in many Eastern countries also exceeds the existing standing of LSS. This paper intends to analyze the existing LSS implementation status in Jordan empirically. This research examined LSS with the questionnaire tool from a variety of perspectives.

\section{Literature Review}

A Toyota Production System (TPS), built by Toyota engine corporation Taiichi Ohno, is planned to eliminate waste from the manufacturing method of all kinds and anomalies (Emiliani, 2006). Output from TPS gave the global manufacturing industries broad acceptance, later spreading to other non-conventional industries. The GPT theory followed the development of the most widely known word "lean output" (Ohno, 1988). Lean on Value - Added Management of Production (or 'muda') (Gnoni et al., 2013). The casualties were transportation, over-processing, preparation (Drohomeretski et al., 2014). This waste is reprocessing, substance and blame. Recently, in the literature, Vinodh et al. (2014) mentioned certain kinds of waste. Human creativity and pollution is underutilized. Womack and Jones (2005) conclude that Lean's behavioral transformation is a big obstacle, because its adoption involves a drastic shift in stakeholder perception and in the manner that expenses and losses are correlated with them. Using lean methods and techniques that aim to minimize waste to the optimal amount, tools and techniques should be taken into line with the overarching approach and values for achieving performance (Antony et al., 2014).

Kajdan (2008) gave a number of specific slimming principles, concepts, and emphasized that the sum of all resources (including time) utilized in a company's 
activities was that. Nevertheless, other significances, including logos and advertising appear as value creation and waste removal. You can be a profitable company with a lean method from the inefficient manufacturing framework to improved performance, waste disposal, setbacks and full cost reduction.

Six Sigma technology is one of the most popular methods today. Throughout the mid-1980s, Motorola Corporation launched it. The Greek letter SIGMA, the calculation difference from the average in a given market period, is the statistical expression "normal difference." "Deviation" results in products and services that no longer satisfy customer requirements (Department, 2009). Six Sigma seeks to reduce any process differences (Näslund, 2008; Chakrabarty and Tan, 2007; Antony, 2004), reduce production costs and services, reduce cost-effectiveness, increase customer satisfaction and improve the quality of copy defects, and reduce them to about 3.4 million parts (Andersson et al., 2014).

Six Sigma listens to Voice of Consumers (VOC) to assess their desires and transforms them into a product or service model (Usmen, 2015). The blocks have been strengthened to form the basis of a comprehensive management and management system. The results were amazing and many Motorola goods improved their efficiency to reach Six Sigma (Reosekar and Pohekar, 2014). The results were amazing. Six Sigma stresses the reduction and avoidance of business process errors and extremely data-based, along with the product (production), operation (delivery) and operational processes (cycle time), within an enterprise.

\section{a. Six Sigma and Lean}

Lean and the Six Sigma have been pursuing different routes since the 1980's, when the principles were first identified and applied in the Ford plant in Michigan, USA in 1913. Then the Japanese improved with the Toyota production system, and with the Motorola research center, Six Sigma's dawn in the United States (Laureaniet et al., 2013).

\section{b. Lean Six Sigma}

By the turn of the 20th century, researchers found that the concepts of Lean and Six Sigma had advanced effectively. The number of articles publishing Lean's and Six Sigma's (Naslund, 2008) performance results has therefore increased. Although Lean and Six Sigma were linked in separate spaces, their destinations were comparable. Most researchers started to incorporate Lean Six Sigma principles in the late 1990s. Between 1997 BAE Systems Controls made initial efforts to implement Lean Six Sigma in 1999 and Maytag in 1999.

Scholars studied how 'Modern Six Sigma' brought the principles of Lean and Six into consideration (Bendell, 2006). Lean Six was first used as a Lean Six Sigma in a literary setting between the book named "Lean Six Sigma combining six signs with light pace" (George, 2002). The Lean Six Sigma Methodology (LSS) blends the principles of the Six Sigma method with the philosophy of light-waste reduction 
(Anderssonet et al., 2014). LSS was a common tool for improving manufacturing performance at organizational level (Albliwi et al., 2015) and elsewhere (Chiarini, 2012). In some fields of Fortune 500, its usage was often defined as an embrace of creativity (Mashinini-Dlamini and VanWaveren, 2013). Because LSS is a modern theory, a variety of experts in different fields have contributed to the research and growth of LSS (Enoch, 2013).

Maleyeff, (2012) discusses LSS principles and development problems. The approach used in his analysis is a survey of the LSS knowledge predictions of business analysts. The study includes four main findings impacting LSS practices, seriousness recognition, robust risk management, regional issues in the workforce and global regulatory concerns. A historical examination and ongoing progress showed that Saudi private and public organizations have ISO 9000, ISO 9001, ISO 14001 and TQM for their main application (Alsaleh, 2007; Magd, 2006). The condition of methodological work in Saudi Arabia was described in Al-Darrab et al. ( 2013) and Al Rubaish (2010). Further research concentrate on universal consistency criteria such as sequence ISOs (Magd, 2006; Curry and Kadha, 2002; Mariottia et al., 2014) and CI processes, such as TQMs (Alsaleh, 2007).

Students, however, agreed that the analysis concentrated on the inability of Saudi Arabia organizations to use LSS is in theoretical studies. In Saudi Arabia, however, many case studies on the LSS health industry have been published. In a public health unit, the first work on Lean Six Approaches Kit techniques and tactics was conducted to reduce wait time from 24,5 to below 10 minutes in the vaccine room (El Faiomy and Shabana 2012). An international review of patient activity was performed in emergency departments (Al Owad et al., 2013). In a fascinating case study, Reddy and Al Shammari (2013 ) reported rationalizing the new discharge process in King Khalid Hospital.

Two case studies on the adoption of LSS in the construction sector were also published. The process Lean, Green and Six Sigma were first seen in the building industry (Banawi and Bilec, 2014). Jubail Industrial City, Saudi Arabia, has published a second example, which would reduce building time for 405 community villas (Kim et al., 2012). The case studies are published in four high numbers by leading oil and petrochemical organizations, Saudi Aramco and King Fahad University (Bubshait and Al-Dosary, 2014). Six Sigma founded in Obaidullah (2005) applied to both UK manufacturing and service companies. Kateeb (2009) reported strong statistical correlations with Six Sigma changes in error reduction, Six Sigma's essential statistical relationship, and Homeland Commercial and Finance Process. Reddy and Reddy (2010) showed a $2.7 \%$ to $0.65 \%$ decrease in bearing ring rejection levels at the production plant in Hyderabad, Northwest Ohio, USA. 


\section{Hypothesis Development}

Improving, monitoring and controlling organizational output is a global issue. It is not inherently limited to one particular business, industry or country. Various approaches and techniques have been utilized to enhance efficiency. Yeh et al. (2011) stated that Lean Six Sigma strengthens operational processes and Soare (2012) has shown strong interest in continuous quality management work over the last few years. Abu-Hameeda (2013) acknowledged that Lean Six Sigma provides high quality items that maximize consumer loyalty. Junankar et al. (2014) also overcome the multiple problems confronting the pharmaceutical industry to achieve improved outcomes. Koripadu and Subbaiah (2014) clarified the effective usage of Lean and Six Sigma Programs to take constructive measures to address challenges and enhance process reliability and performance. Thus, this research is adapted to answer the main question: Do Lean Six Sigma elements (deficiency, production, waiting time, transportation, inventory, movement, additional processing and unused talent) affect the performance of companies? The following null hypothesis was established to answer this problem:

H01: Default has no impact on the performance of the Organization.

H02: Over production has no impact on the performance of the Organization.

H03: Waiting time has no impact on the performance of the Organization.

H04: Transportation has no impact on the performance of the Organization.

H05: Inventory has no impact on the performance of the Organization.

H05: Motion has no impact on the performance of the Organization.

H06: Processing has no impact on the performance of the Organization.

H07: Unused talent has no impact on the performance of the Organization.

\section{Research Methodology}

An online survey was performed to determine LSS status in Jordan. After evaluating various types of survey techniques, a concise analysis was performed (Forza, 2009). That is the only direction in which the present rates of acceptance by Jordanian organisations of Lean Six SIGMA can be identified (Forza, 2009; Saunders et al., 2009). A detailed research, training etc., of the Lean / Six Sigma systems and many questions have been asked to provide a deeper understanding of the historical knowledge of the organisation. The Likert scale, which was a type of scale used most often, has also been introduced to enable participants to reply to more partial questions and to demonstrate that they had or had no opinion (Easterby-Smith et al., 2012), because they were able to respond with each other (Easterby-Smith et al., 2013).

\subsection{Process and Method of Sampling}

The definition of target population and sample selection was recognized as a key phase of the investigation because sample quality is predicted to generalize the 
results (Gay and Diehl 1992; Collis and Hussey 2003). The authors concentrate on Saudi organisations utilizing Lean or Six Sigma with the systemic random sample for this study for at least one year. Researchers also established a series of standards for ensuring the collection of a suitable organizational sample (Eisenhardt, 1989; Yin, 1994; Voss, 2009). For the selection of the sample it is necessary, in order to assess the status of LSS, to look at several issues in a given organization (Chakrabarty and Chuan Tan, 2007) the second part of the studies aims to learn about the Lean and Six-Sigma's Lean and Six Sigma implementation, or both for at least one year.

\section{Empirical Results}

The report was circulated to 264 organisations in Jordan, utilizing e-mail addresses and data banks through Saudi Chambers Council. Dissemination experts Enabler Lean / Six Sigma were approached through experts in the most relevant companies, and they requested to take part in the research. It was targeted at people like practicioners, administrators, Lean / Six Sigma employees, etc. The analysis was administered by Six Sigma. It was therefore ordered in each company to nominate people who follow the selection criteria of samples. Afterwards they received the telephone and the e-mail requesting this study to be conducted and the connection to other Lean/Six Sigma team leaders, Lean/Six Sigma managers and their organisations. The analysts examined the two aspects of the study and provided a good impression of the complexity of the LSS application in the organizations.

\subsection{Community Detail}

There were two forms of verification. Several data points have been used to verify the validity of content (such as articles, papers, reports, theses, articles and interviews with World Wide Web and Jordanian organizations). A judge jury was used to verify the authenticity of the results. Kaiser-Meyer-Olkin (KMO) statistic confirmed the validity of the building during the main component analysis. Factor 1 shows a range of 0.765 to 0.899 and 0.903 to 70.213 to KMO for all independent variables (Cerny and Kaiser 1977). To validate reliability, we used Cronbach alpha. This can consider greater than 60 percent alpha (Sekran, 2003). As shown in Table 1, all variables accept alpha Cronbach coefficients, although the carriage and inventory were respectively 0.598 and 0.554 .

Table 1. Mean, SD and Ranking of the variables

\begin{tabular}{|l|l|l|l|l|}
\hline Item & Mean & SD & t- value & Rank \\
\hline Defects & 4.52 & 0.26 & 42.89 & High \\
\hline Over production & 4.23 & 0.34 & 41.90 & High \\
\hline Waiting time & 4.98 & 0.65 & 30.54 & High \\
\hline Transportation & 4.59 & 0.59 & 34.12 & High \\
\hline Inventory & 4.64 & 0.45 & 32.16 & High \\
\hline Motion & 4.12 & 0.82 & 20.21 & High \\
\hline
\end{tabular}




\begin{tabular}{|l|l|l|l|l|}
\hline Extra processing & 4.34 & 0.62 & 21.90 & High \\
\hline Non-utilized & 4.20 & 0.31 & $26 / 23$ & High \\
\hline Lean Six Sigma & 4.02 & 0.38 & 58.91 & High \\
\hline Business performance & 4.53 & 0.20 & 32.90 & High \\
\hline
\end{tabular}

Source: Own calculations.

\subsection{Kaiser-Meyer-Olkin Method (KMO)}

The EFA attempts to determine the nature of the processes that influence a number of answers. The adequacy approximation of the sample from Kaiser-Meyer-Olkin (KMO) is used to assess further the factorability of the samples. This index compares the size of the observed correlation coefficients with the size of the partial correlation coefficient. The KMO rating varies from 0 to 1 . For factor research, a minimum value of 0.6 is recommended (Tabachnick and Fidell, 2001). Hair et al. (2010) indicated that KMOs of 0.880 or above are commendable; middling of .80 to .70 ; decent of .70 to .60; awful of .60 to .50 is commendable. This review is capable of KMO 0.89 (Table 2) estimation. The meaning suggested that the association between pairs and factor analysis may also be easily clarified by certain factors to the research.

Table 2. KMO and Bartlett's Test

Source: Own calculations.

\begin{tabular}{lll} 
Kaiser-Meyer-Olkin Measure of Sampling Adequacy. & .903 \\
\hline \multirow{3}{*}{ Bartlett's Test of Sphericity } & Approx. Chi-Square & 5320.415 \\
\cline { 2 - 3 } & Df & 818 \\
\cline { 2 - 3 } & Sig. & .000 \\
\hline
\end{tabular}

\subsection{Exploratory Factor Analysis}

Factor analysis is used to reduce data for the purposes of the description. This math approach aims to which different associated variables into ones that are autonomous. The relation between many variables may be analyzed by means of a collection of fundamental parameters known as 'component' and 'dimensions.' In order to sum up the details present in the initial variables, an exploratory component analysis was used to simplify the details into smaller variables or factors for better mathematical interpretation of the measured variables / factors (Hair, Anderson, Tham, and Black, 2010).

Once the factor analysis had been established as an adequate technician, the objects were subject to the main axis factoring and the exploratory factor analysis for Varimax rotation (Arnold and Reynolds, 2003; Hair et al., 1998; Nunnally, 1978). A multivariate method is focused on the assigning of data to the dimension with the highest variabilities (Pallant, 2007; Tabachnick and Fidell, 2001). Kaiser proposed that Varimax would rotate in 1958 to see if groupings represent the same meaning (Kaiser, 1958). 
The corresponding component matrix was presented after estimation of the number of variables. The variables were reversed to make understanding possible. Diekhoff (1992) said the variables which explain why their value is explained by the most variance factors. For this study, the variables were rotated according to the Varimax criteria. Loads above 0.40 were known to improve factor matrix perception (Hair et al., 1998; Rossiter, 2002).

\section{Table 3. Exploratory Factor Analysis (EFA)}

\begin{tabular}{|c|c|c|c|c|}
\hline No. & Variable & $\begin{array}{l}\text { Factor } \\
\text { Loading }\end{array}$ & $\begin{array}{l}\text { Cronbach } \\
\text { alpha }\end{array}$ & AVE \\
\hline 1 & $\begin{array}{l}\text { Lean Six Sigma reduces defects and aids in cost } \\
\text { control. }\end{array}$ & 0.795 & 0.754 & 0.578 \\
\hline 2 & $\begin{array}{l}\text { Lean Six Sigma reduces waste and improves the } \\
\text { process speed. }\end{array}$ & 0.759 & & \\
\hline 3 & $\begin{array}{l}\text { Multiple departments (such as } \mathrm{R} \& \mathrm{D} \text {, marketing } \\
\text { and sales, and manufacturing) coordinate in the } \\
\text { product/service development process. }\end{array}$ & 0.75 & & \\
\hline 4 & $\begin{array}{l}\text { Overall, in the product or service design } \\
\text { process, we make an effort, to include only the } \\
\text { steps which are clearly needed. }\end{array}$ & 0.721 & & \\
\hline 5 & $\begin{array}{l}\text { Our company systematically uses a set of } \\
\text { measures (such as defects per million } \\
\text { opportunities, sigma level, process capability } \\
\text { indices, defects per unit, and yield) to evaluate } \\
\text { process improvements. }\end{array}$ & 0.72 & & \\
\hline 6 & $\begin{array}{l}\text { To what extent do you agree that your company } \\
\text { places a high priority on the following? This } \\
\text { company is production oriented. The major } \\
\text { concern is with getting the job done. People } \\
\text { aren't very personally involved. }\end{array}$ & 0.701 & 0.764 & 0.586 \\
\hline 7 & $\begin{array}{l}\text { The glue which holds this company together is } \\
\text { an emphasis on tasks and goal accomplishment. } \\
\text { A production orientation is shared. }\end{array}$ & 0.629 & & \\
\hline 8 & $\begin{array}{l}\text { Our Company is able to link the continuous } \\
\text { improvement initiatives with the overall } \\
\text { strategy. }\end{array}$ & 0.813 & & \\
\hline 9 & $\begin{array}{l}\text { Management provides personal leadership for } \\
\text { quality products and quality improvement. }\end{array}$ & 0.78 & & \\
\hline 10 & $\begin{array}{l}\text { Clear work or process instructions are given to } \\
\text { employees }\end{array}$ & 0.761 & & \\
\hline 11 & Lean Six Sigma improves on time delivery. & 0.749 & 0.81 & 0.508 \\
\hline 12 & The products are instantly & 0.737 & & \\
\hline 13 & $\begin{array}{l}\text { Authorization for different activities is instantly } \\
\text { given }\end{array}$ & 0.711 & & \\
\hline 14 & Faulty equipment's are instantly replaced & 0.818 & & \\
\hline 15 & $\begin{array}{l}\text { Proper mediators are there who help in } \\
\text { transportation of good from one place to another }\end{array}$ & 0.804 & 0.798 & 0.506 \\
\hline 16 & The goods reach the final destination in perfect & 0.796 & & \\
\hline
\end{tabular}




\begin{tabular}{|c|c|c|c|c|}
\hline No. & Variable & $\begin{array}{l}\text { Factor } \\
\text { Loading }\end{array}$ & $\begin{array}{l}\text { Cronbach } \\
\text { alpha }\end{array}$ & AVE \\
\hline & state & & & \\
\hline 17 & The goods are timely distributed & 0.743 & & \\
\hline 18 & The raw materials are available & 0.538 & 0.702 & 0.503 \\
\hline 19 & $\begin{array}{l}\text { In case of shortage the raw materials are } \\
\text { arranged at urgent basis }\end{array}$ & 0.712 & & \\
\hline 20 & The inventory is & 0.663 & & \\
\hline 21 & $\begin{array}{l}\text { The tools are readily available during } \\
\text { production }\end{array}$ & 0.661 & 0.754 & 0.485 \\
\hline 22 & $\begin{array}{l}\text { Certain people are assigned to do certain tasks } \\
\text { in different departments }\end{array}$ & 0.65 & & \\
\hline 23 & $\begin{array}{l}\text { Walking around different departments is not } \\
\text { acceptable }\end{array}$ & 0.631 & & \\
\hline 24 & Motion of people affects the production process & 0.497 & & \\
\hline 25 & Lean Six Sigma reduces process variability & 0.789 & 0.834 & 5.7 \\
\hline 26 & $\begin{array}{l}\text { We constantly study and review our key } \\
\text { business processes to make improvements. }\end{array}$ & 0.773 & & \\
\hline 27 & $\begin{array}{l}\text { The good produced in excess are sold at reduced } \\
\text { prices }\end{array}$ & 0.681 & & \\
\hline 28 & The goods produced in excess are discarded & 0.646 & & \\
\hline 29 & $\begin{array}{l}\text { The items which are not used are kept in the } \\
\text { inventory }\end{array}$ & 0.795 & 0.702 & 5.1 \\
\hline 30 & $\begin{array}{l}\text { The items which are in the inventory are later } \\
\text { utilized in other products as substitutes }\end{array}$ & 0.728 & & \\
\hline 31 & The items are discarded & 0.518 & & \\
\hline 32 & $\begin{array}{l}\text { The items reduces the profits a company is } \\
\text { getting }\end{array}$ & 0.686 & & \\
\hline 33 & Lean Six Sigma & 0.627 & 0.799 & 5.5 \\
\hline 37 & Business performance & 0.661 & 0.848 & 5.4 \\
\hline
\end{tabular}

Source: Own calculations.

The loading factor is given in the column below. For psychometric reasons the factor loading is considered to be 0.3 or higher (Hair et al., 2010). After the analysis of the Exploratory Factor 32 elements of the ORS chart, covering ten measure dimensions, have been maintained. To reassess the precision of the metric, Cronbach alpha coefficients have been used. The coefficients were between 0.518 and 0.818 in value (Table 3). These values suggested precise measurements and could be used for further analysis.

Table 3. Validity and Reliability Test

\begin{tabular}{|l|l|l|l|l|l|l|l|}
\hline Variable & $\begin{array}{l}\text { No. of } \\
\text { Items }\end{array}$ & $\begin{array}{l}\text { Cronbach } \\
\text { alpha }\end{array}$ & $\begin{array}{l}\text { Factor } \\
\mathbf{1}\end{array}$ & $\begin{array}{l}\text { KMO } \\
\text { Test }\end{array}$ & $\begin{array}{l}\text { Barlett's } \\
\text { test }\end{array}$ & $\begin{array}{l}\text { Explained } \\
\text { Variance }\end{array}$ & Sig. \\
\hline Defects & 5 & 0.654 & 0.765 & 0.903 & 24 & 70.213 & 0.000 \\
\hline $\begin{array}{l}\text { Over } \\
\text { production }\end{array}$ & 5 & 0.764 & 0.724 & & & & \\
\hline Waiting time & 5 & 0.810 & 0.899 & & & & \\
\hline
\end{tabular}




\begin{tabular}{|l|l|l|l|l|l|l|l|}
\hline Transportation & 5 & 0.598 & 0.759 & & & & \\
\hline Inventory & 5 & 0.554 & 0.875 & & & & \\
\hline Motion & 5 & 0.834 & 0.821 & & & & \\
\hline $\begin{array}{l}\text { Extra } \\
\text { processing }\end{array}$ & 5 & 0.602 & 0.801 & & & & \\
\hline Non-utilized & 5 & 0.699 & 0.765 & & & & \\
\hline $\begin{array}{l}\text { Lean Six } \\
\text { Sigma }\end{array}$ & 8 & 0.848 & & & & & \\
\hline $\begin{array}{l}\text { Business } \\
\text { performance }\end{array}$ & 10 & 0.702 & & & & & \\
\hline
\end{tabular}

Source: Own calculations.

\subsection{Confirmatory Factor Analysis (CFA)}

SEM is an increasingly popular method for data analysis in Operations Management (Sha and Goldstein, 2006). The varimax exploratory factor analysis (EFA) was carried out on the LSS constructions. The Kaiser-Meyer-Olkin (KMO) value of sample adequacy is 0,903 over 0,7 and shows that the real knowledge for the study of the principal variable is appropriate. Bartlett test ( $\mathrm{p}$ value 0.001) performs a thorough sphericity test, which indicates an appropriate interaction between the objects to be examined. For this item, a minimum load of 0.4 per object per factor is considered necessary (Hatcher, 1994). Table 4 indicates that the average experience of interviewees at the point of the Leans six Sigma application varies from 4.04 to 4.64 and the specific variations vary from 0.31 to 0.54 . In identifying variables the types, normal variables, amounts, $t$ ratings, and meaning are used. These findings indicate that the significance of Lean Six Sigma variables is accepted. The average of the total Lean Six Sigma variables is 4.34 with a standard deviation of 0.25 , which implies that the Lean Six Sigma variables are solid. Eventually, the cumulative findings indicate that Lean Six Sigma is being implemented by Jordanian companies very substantially $(t=58,91>1,96)$. Table 4 further shows that the average market output is at 4,12 with the standard deviation of 0,34 and that Jordanian businesses have large levels of company efficiencies $(t=32,90>1,96)$.

Table 4. Fit Indices for CFA Measurement Model

\begin{tabular}{|l|l|l|l|}
\hline Fit Index & Recommended Value & Source & Value \\
\hline Chi-Square/ df & $<3.0$ & Kline, 2004 & 1.458 \\
\hline GFI & $>0.80$ & $\begin{array}{l}\text { Holmes-Smith \& } \\
\text { Coote, 2002 }\end{array}$ & 0.834 \\
\hline AGFI & $>0.80$ & Hair et al., 1998 & 0.801 \\
\hline RMSEA & $<0.07$ & Steiger, 2007 & 0.045 \\
\hline CFI & $>0.80$ & Hair et al; 2006 & 0.876 \\
\hline RMR & $<0.1$ & Hu \& Bentler, 1999 & 0.90 \\
\hline
\end{tabular}

Source: Own calculations.

CFA output contains fit index. Monitoring of many performance indices for model fit assessment is advised, even if the model evaluation rules are not defined. Fitness 
indexes (CFI), performance index (GFI), Modified Goodness Index (AGFI), Comparative Fit Index ( CFI), and RMSEA were the most frequently mentioned fit indices. Monitoring of Chi-square, CFI and RMSEA is recommended. Enable model Indices fell into 3 categories: Complete indices, Gradual indexes, Parsimonious indexes. The incoherence of inferred and observable covariance matrices can be assessed by absolute indices. Usually, absolute indexes are GFI (Goodness Match Index) and SRMR (Standard Root Mean Square Residual). Parsimonious indices calculate the discrepancy, as well as the sophistication of the process, between predicted and observed covariance matrices. The commonly reported indices are AGFI and RMSEA (root mean square approximation error). Incremental indexes equate the new norm with the one. The indicated incremental indexes are CFI (Compare Fit Index) and NFI (Normed Fit Index).

Figure 1. CFA Path Diagram

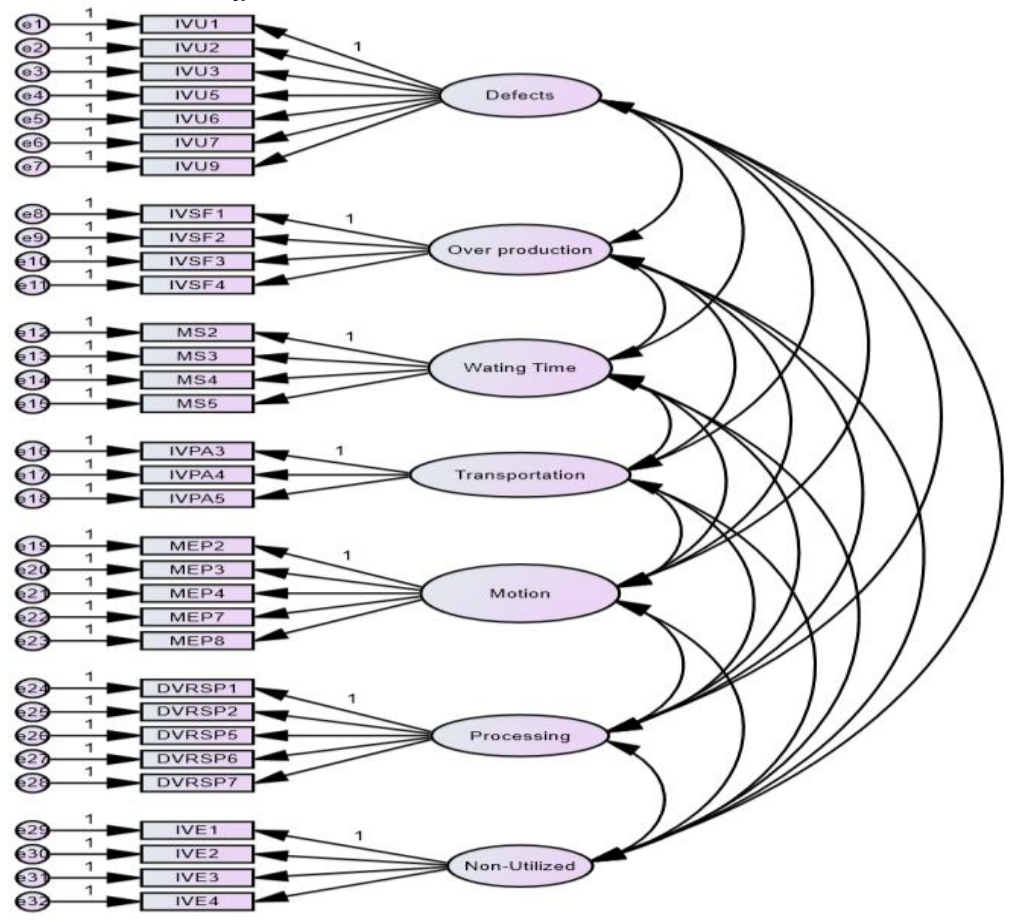

Source: Own calculations.

The analysis includes: Chi-square, Chi-square / df, GFI, AGFI, RMSEA, CFI (Hair et al., 1998; Shumacker, 2004). Chi-square checking with freedom standard and corresponding $\mathrm{p}$ meaning is mandatory. Chi / df has a spectrum of 1 and 5 (Chin et al., 1997; Salisbury et al., 2002). A meaning below 3 is fine (Kline, 2004). For the GFI and AGFI, researchers recommend beyond 0.9 (Joreskog and Sorbom, 1993). Also acceptable are GFI scores over 0.80 and AGFI scores over 0.80 (Hair et al., 1998). A good fit predictor should be RMSEA below 1.00 (Shumacker and Lomax 2004). For RMSEA the fit varies between 0.08 and 0.10 (Hair et al., 2006) and 
ideals of 0.05 to 0.08 (MacCallam et al., 1996), although a maximum 0.07 is considered adequate recently.

The CFI values vary from zero to three, where the fit-model values are stronger $(\mathrm{Hu}$ and Bentler 1998). The CFI values above 0.865 have been recorded to match adequately (Chou et al., 1995). Overall, the model has good fit if the majority of indications indicate good fit (Schreiber et al., 2006). For existing models and hypotheses less severe values are considered (Vassend and Skrondal, 1997). The findings of the CFA model suggest a strong fit for the Cause and Effect models in this report. Chi-square / df was 1.458 and 1.389 respectively $(\mathrm{p}<0.05)$.

\subsection{Hypothesis Testing Path Analysis}

The structural equation model was determined to test the hypothesis after observing the precision and dimensionality of the measurement scales. As shown in Table 5, faults affect business performance over production, time, transport, inventory, movement and processing.

Figure 2. Hypothesis testing path analysis

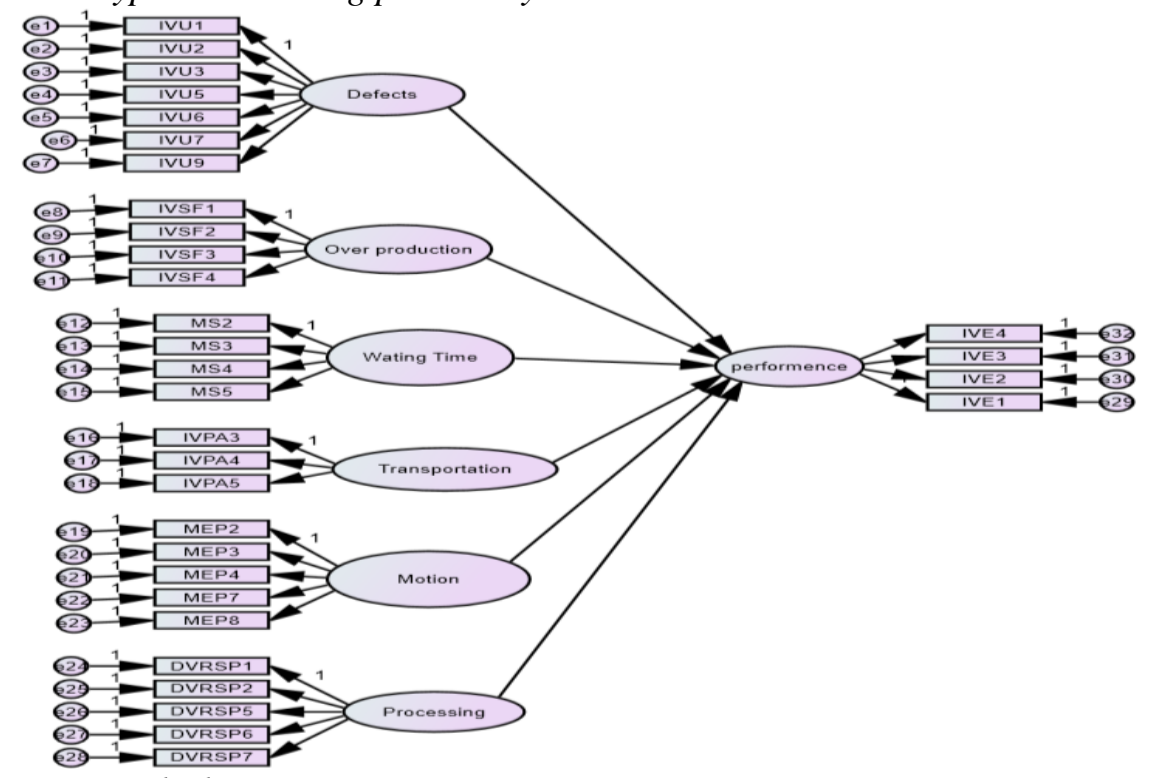

Source: Own calculations.

According to H01, there would be no effect of defects on market results however as seen in Table 5, the value of $\mathrm{p}$ is less than $5 \%$ so that this is not agreed and the alternate hypothesis is approved for $\mathrm{H} 01$. In the case of $\mathrm{H} 02$, this hypothesis is also rejected since the value of $\mathrm{p}$ is less than 5\%. Time affects the efficiency of companies as shown in Table 5, the p-value of performance transport is $32,4 \%$, which has an impact on performance, $\mathrm{H} 04$ is rejected. The theories of H05, H06 and $\mathrm{H} 07$ were all dismissed because the p-value reached 5 percent $(12.5 \%, 97.8 \%$ and 
$13.2 \%$ ) owing to the effect on market efficiency of production, transport and distribution.

Table 5. Hypothesis testing

\begin{tabular}{|l|l|l|l|l|l|l|l|}
\hline & & & $\begin{array}{l}\text { Esti } \\
\text { mate }\end{array}$ & S.E. & C.R. & P & Result \\
\hline Performance & $<--$ & Defects & .180 & .053 & 4.520 & 0.019 & Not Supported \\
\hline Performance & $<--$ & $\begin{array}{l}\text { Over } \\
\text { production }\end{array}$ & .219 & .045 & 3.867 & 0.027 & Not Supported \\
\hline Performance & $<--$ & Time & .167 & .048 & 5.476 & 0.0002 & Not Supported \\
\hline Performance & $<--$ & Transportation & .045 & .045 & 4.986 & 0.001 & Not Supported \\
\hline Performance & $<--$ & Inventory & .140 & .047 & 3.959 & 0.023 & Not Supported \\
\hline performance & $<--$ & Motion & 0.45 & .046 & 4.028 & 0.048 & Not Supported \\
\hline Performance & $<--$ & Processing & 0.167 & .048 & 3.476 & 0.004 & Not Supported \\
\hline
\end{tabular}

Source: Own calculations.

\section{Conclusion}

For successful implementation of Lean Six Sigma, the ability to allocate resources is essential. In order to promote the implementation of Lean Six Sigma and boost results in terms of human capital through preparation, engagement and mobilization, infrastructure growth is required. Management will allow use of Lean Six Sigma growth steps by successful monitoring, documenting and implementation of six Lean Sigma methods, in order to ensure corporations to optimize their product utilization and maximum capacity and boost their strategic advantages. This research helps managers to organize and apply Lean Six Sigma, products to boost the business and economic performance. The partnership between LM and Six Sigma is real. Six Sigma provides LM with specific product improvements and activities. Integration of LM and Six Sigma allows consistent individual method and product growth. The application of Lean Six Sigma calls for improved organizational culture and a willingness to learn and work as a team. The shortage of money will even improve managers' capacity and provide competitive advantages.

With the effective implementation of Lean Six Sigma the ability to disperse resources is important. In order to promote the implementation of Lean Six Sigma and enhance the outcomes of human capital through preparation, engagement and mobilization, infrastructure growth is required. The implementation will take advantage of Lean Six Sigma growth steps through precise measurement, monitoring and administration of six Lean Sigma practices to optimize product utilization and maximum capacity and improve its competitive advantages.

In their own logical context, managers may establish a causal link between individuals, systems, goods and performance. This research helps experts and judges to recognize new processes and methods of development that add value and promote competitive advantages. This also helps to create basic values that can be used as 
positive indicators. The study also assists managers in designing policies and regulations that promote improvement, growth and the management of deficiencies. It also supports organizations to address challenges and acquire and improve Lean Six Sigma strategies. It supports organizations.

Finally, Lean Six Sigma's approaches allow management to render decision-making and problem-solving constructive rather than reactive. It also increases knowledge of production systems, products and ties. In any organization and scale, Lean Six Sigma may be used anywhere. Further work is also essential to allow the usage of Lean Six Sigma criteria for all pharmaceutical activities. The results revealed that the participants agreed on high levels of value and execution and on the output of each Lean Six Sigma vector (default, time to create, wait, transfer, production, travel, extra processing and unused talent). The results show that the relationships between Lean Six Sigma and its distribution are medium to large except for small and unimportant. It ensures that the Lean Six Sigma factors have mutual influence.

The results are linked directly to the Lean Six Sigma ranking. The link between Lean Six Sigma's overall performance and its market is also good. Furthermore, the current study shows that all Lean Six Sigma variables affect the business efficiency of Jordanian organisations. This defect mostly affects movement, inventory, transport, production and unused capacity, and has little influence on the performance of Jordan in terms of time and processing. Finally, all the waste variables influencing business efficiency, including competitive performance, profitability and demand assessment, need to be removed by Jordanian organizations strongly. This study helps managers to plan and conduct Lean Six Sigma. Improvement of the sector and services for economic profile. The alliance LM-Six Sigma is probable. Six Sigma provides LM further enhancements and efficiency standards. Integrating LM and Six Sigma means continuously improving staff, processes and products. The analytical insight and a desire to know and work as a team with Lean Six Sigma needs to improve. Resource scarcity will improve management capabilities and bring competitive advantages.

Managers in their own rational context will create a causal association between individuals, systems, goods, and performance. This study helps experts and judges to identify alternative systems and strategies for production that add value and develop competitive advantages. This also helps to establish simple definitions that can be viewed as performance indicators. The analysis also helps managers to create policies and regulations that promote change, development and the management of deficiencies. It also supports organizations in addressing challenges and acquiring and developing Lean Six Sigma strategies.

The results reveal that, except for the small and unimportant, the relations between Lean Six Sigma and transport are medium to good. It demonstrates variables of Lean Six Sigma impacting one another. The outcomes of each Lean Six Sigma component 
are closely related. Lean Six Sigma 's overall performance and business performance are also strong.

The present study reveals, however, that all Lean Six Sigma variables influence Jordan's business efficiency. The most important consequence of the defect is shipment, then development, transportation, productivity and idle power, while the output of Jordan is influenced by further manufacturing and waiting time. Finally, Jordanian companies think it is necessary to incorporate all waste variables that influence company efficiency, such as competitiveness, profitability and stock market evaluation.

\section{Implications and Limitations}

For successful implementation of Lean Six Sigma, the ability to allocate resources is essential. In order to promote the implementation of Lean Six Sigma and boost results in terms of human capital through preparation, engagement and mobilization, infrastructure growth is required. Management will allow use of Lean Six Sigma growth steps by successful monitoring, documenting and implementation of six Lean Sigma methods, in order to ensure corporations optimize their product utilization and maximum capacity and boost their strategic advantages.

Regarding limitations employees of only few firms were contacted so the results cannot represent the employees of all the organizations, only one aspect of Lean six Sigma was taken while there are other aspects as well and only scale was taken in the study.

\section{References:}

Abdelhadi, A., Shakoor, M. 2014. Studying the efficiency of inpatient and outpatient pharmacies using lean manufacturing. Leadership in Health Services, 27(3), 255267.

Abdelhadi, A.N. 2014. Application of Toyota's Production System to Reduce Traffic Accidents in Abha's Region - Case Study. Proceedings of the 2014 International Conference on Industrial Engineering and Operations Management, Bali, Indonesia, January 7-9.

Abu-Hameeda, A. 2013. The impact of implementing Total Quality Management standards in building differentiation strategy of Jordanians pharmaceutical manufacturing companies. Unpublished Master thesis, Middle East University.

Agus, A., Iteng, R. 2013. Lean production and business performance: the moderating effect of the length of lean adoption. Journal of Economics, Business and Management, 1(4), 324-328.

Ahmad, S. 2013. Service sector performance management through six sigma. International Journal of Innovative Research \& Development, 2(13), 346-350.

Al-Darrab, I.A., Gulzar, W.A., Ali, K.S. 2013. Status of implementation of safety, quality and environmental management systems in Saudi Arabian industries. Total Quality Management \& Business Excellence, 2(4), 336-354.

Al-Maghrabi, T., Dennis, C. 2011. What drives consumers' continuance intention to e- 
shopping? International Journal of Retail \& Distribution Management, 39(12), 899926.

Al-Sadat, M.A., Robertson, K.E. 2007. Using Lean Six Sigma to Increase Productivity in Generating the Digital Terrain Model (DTM). Saudi Aramco company, unpublished work.

Al-Shafei, A.I., Abdulrahman, K., Al-Qumaizi, K.I., El-Mardi, A.S. 2015. Developing a generic model for total quality management in higher education in Saudi Arabia. Medical Teacher, 37(S1), S1-S4.

Al-Sulimani, T. 1995. Total Quality Management in Saudi Manufacturing Industry- A survey based implementation plan. The Fourth Saudi Engineering Conference, 2, 58 November, King Abdulaziz University, Jeddah.

Albliwi, S., Antony, J., Lim, S.A. 2015. A Systematic Review of Lean Six Sigma for the Manufacturing Industry. Business Process Management Journal, 21(3), 665-691.

Albliwi, S., Antony, J., Lim, S.A., Ton van der Wiele. 2014. Critical failure factors of Lean Six Sigma: a systematic literature review. International Journal of Quality \& Reliability Management, 31(9),1012-1030.

Aleem, H., Anwar, S., Shariff, I., Abdul Aziz, S. 2014. Six sigma application: an order management system. IOSR Journal of Humanities and Social Science, 19(1), 95100.

Alharthi, A.A., Sharaf, M.A., Aziz, T. 2014. An Integrated Approach Lean Six Sigma and Risk Management in Entertainment and Media Industry. Proceedings of the 2014 International Conference on Industrial Engineering and Operations Management, Bali, Indonesia, January 7-9.

Almuharib, T.M. 2014. Service Quality Improvement Through Lean Management at King Khalid International Airport in Saudi Arabia. Unpublished doctoral thesis, Plymouth University.

AlSagheer, A. 2011. Six sigma for sustainability in multinational organizations. Journal of Business Case Studies, 7(3), 7-16.

Alsaleh, N.A. 2007. Application of quality tools by the Saudi food industry. The TQM Magazine, 19(2), 150-161.

Alsmadi, M., Lehany, B., Khan, Z. 2012. Implementing Six Sigma in Saudi Arabia: An empirical study on the Fortune 100 firms. Total Quality Management \& Business Excellence, 23(3-4), 263-276.

Amminudin, K.A., Enezi, T.S., Jubran, M.A., Hajji, A.T., Enizi, A.S., Bedoukhi, Z.F. 2011. Gas plant improves C3 recovery with Lean Six Sigma approach. Oil and Gas Journal, 109(19), 102-109.

Antony, J. 2009. Reflective practice, Six Sigma vs TQM: some perspectives of leading practitioners and academics. International Journal of Productivity and Performance Management, 58(3), 274-279.

Antony, J., Banuelas, R. 2002. Key ingredients for the effective implementation of Six Sigma program. Measuring Business Excellence, 6(4), 20-27.

Antony, J., Desai, D.A. 2009. Assessing the status of six sigma implementation in the Indian industry: Results from an exploratory empirical study. Management Research News, 32(5), 413-423.

Antony, J., Escamilla, J.L., Caine, P. 2003. Lean Sigma. Manufacturing Engineer, 82(2), 40-42.

Antony, J., Kumar, M., Madu, C.N. 2005. Six sigma in small-and medium-sized UK manufacturing enterprises: Some empirical observations. International Journal of Quality \& Reliability Management, 22(8), 860-874. 
Antunes, D., Sousa, S., Nunes, E. 2013. Using project six sigma and lean concepts in internal logistics. Proceedings of the World Congress on Engineering, 3-5 July, London, 1-6.

Arunagiri, P., Babu, A. 2013. Review on Reduction of Delay in manufacturing process using Lean Six Sigma (LSS) systems. International Journal of Scientific and Research Publications, 3(2), 1-4.

Awaritoma, O. 2010. Performance management in lean production. Unpublished Master thesis, Linnaeus University.

Bao, L., Chen, N., Shang, T., Fang, O., Xu, Z., Guo, W., Wang, Y. 2013. A multicenter study of the application of Six Sigma management in clinical rational drug use via pharmacist intervention. Turkish Journal of Medical Sciences, 43(3), 362-367.

Bashir, A., Al-Tawarah, A. 2012. Implementation of six sigma on corrective maintenance case study at the directorate of biomedical engineering in the Jordanian Ministry of Health. Proceedings of the 2012 International Conference on Industrial Engineering and Operations Management, Istanbul, July 3-6, 2508-2516.

Berty, E. 2011. Cigarette reject rate reduction using a Lean Six Sigma approach. Unpublished Master thesis, Royal Institute of Technology.

Bharti, P., Khan, M., Singh, H. 2011. Six sigma approach for quality management in plastic injection molding process: a case study and review. International Journal of Applied Engineering Research, Vol. 6 No. 3, 303-314.

Cavallini, A.G. 2008. Lean Six Sigma as a source of competitive advantage. Unpublished Master thesis, BrighamYoung University.

Cerny, C.A., Kaiser, H.F. 1977. A study of a measure of sampling adequacy for factoranalytic correlation matrices. Multivariate Behavioral Research, 12(1), 43-47.

Chetiya, A.R., Sharma, S. 2014. An analysis of predictor variables for operational excellence through six sigma. Proceedings of the 2014 International Conference on Industrial Engineering and Operations Management, Bali, January 7-9, 1750-1757.

Chinvigai, C., Dafaoui, E., El Mhamedi, A. 2010. Iso 9001: 2000/2008 and lean-six sigma integration toward to Cmmi-Dev for performance process improvement. 8th International Conference of Modeling and Simulation - Mosim'10 - May 10-12, Hammamet, 3-9.

Dahman, T. 2013. The impact of supply chain management to organization performance. Unpublished Master Thesis, Middle East University.

Darabi, Y. 2007. The impact of Market orientation on business performance and website adoption: a study among Iranian SMEs. Unpublished Master thesis, Lulea University of Technology.

DeRuntz, B., Meier, R. 2010. An evaluative approach to successfully implementing six Sigma. The Technology Interface Journal, Vol. 10, No. 3, 1-9.

Desale, S.V., Deodhar, S.V. 2014. Identification and eliminating waste in construction by using lean and six sigma principles. International Journal of Innovative Research in Science, Engineering and Technology, Vol. 3, No. 4, 285-296.

Dey, S.S. 2014. Transforming the Washington, DC, USA, parking meter program using a lean six sigma improvement process. Journal of Transportation of the Institute of Transportation Engineers, Vol. 6, No. 1, 15-32.

Dey, S.S. 2014. Transforming Washington DC's parking meter program using lean six sigma based asset management. Transportation Research Board, 93rd Annual Meeting, No. 14-3302.

Dhawan, S. 2013. Professionalism among the Pupil Teachers: a six-sigma approach in 
Teacher Education. Scholarly Research Journal for Interdisciplinary Studies, Vol. 2, No. 4, 544-557.

Dileep, G., Rau, S. 2010. Patient satisfaction as an indicator of quality care-a study with reference to six sigma implementation in medium scale hospitals. International Journal on Information Sciences and Computing, Vol. 3, No. 1, 27-33.

Divoky, J. 2008. Factors affecting six sigma project selection in the information systems/information technology arena. Review of Business Information Systems, Vol. 12, No. 4, 13-20.

Dwivedi, V., Anas, M., Siraj, M. 2014. Six sigma as applied in quality improvement for injection moulding process. International Review of Applied Engineering Research, Vol. 4, No. 4, 317-324.

Edaily, F. 2014. The possibility of applying six sigma and its role in cost reduction and increasing competition - applied study of advanced technology companies of recycling used materials an empirical study. Unpublished Master Thesis, Zarqa University.

Enoch, O.K. 2013. Lean six sigma methodologies and organizational profitability: a review of manufacturing SMEs in Nigeria. American Journal of Industrial and Business Management, Vol. 3, No. 6, 573-582, available at: www.scirp.org/journal/ajibm.

Franchetti, M. 2014. Continuous improvement and facility redesign through the lean DMAIC Six Sigma approach: a final assembly work unit case study from Ohio, USA. International Journal of Six Sigma and Competitive Advantage, Vol. 8, No. 2, 83-94.

Franchetti, M., Yanik, M. 2011. Continuous improvement and value stream analysis through the lean DMAIC Six Sigma approach: a manufacturing case study from Ohio, USA. International Journal of Six Sigma and Competitive Advantage, Vol. 6, No. 4, 278-300.

Goh, T.N. 2011. Six Sigma as a change agent in quality management. The 55th EOQ Congress and World Quality Congress, Budapest, June 20-23, 1-10.

Goriwondo, W.M., Maunga, N. 2012. Lean Six Sigma application for sustainable production: a case study for margarine production in Zimbabwe. International Journal of Innovative Technology and Exploring Engineering (IJTEE), Vol. 1, No. 5, 87-96.

Habidin, N.F., Yusof, S.R.M., Omar, C.M.Z., Mohamad, S.I.S., Janudin, S.E., Omar, B. 2012. Lean six sigma initiative: business engineering practices and performance in Malaysian automotive industry. IOSR Journal of Engineering, Vol. 2, No. 7, 13-18.

Hajikordestani, R.N. 2007. Taxonomy of lean six sigma success factors for service Organizations. Unpublished Master thesis, University of Central Florida.

Huang, Y. 2013. Applying linear programming method in six sigma approach to develop a truck planning tool. Unpublished Master thesis, University of Wisconsin-Stout.

Jaakkola, M. 2006. Strategic marketing and its effect on business performance: moderating effect of country-specific factors. Unpublished Master thesis, Helsinki University of Technology.

Jaglan, P., Kaushik, P., Khanduja, D. 2011. Six sigma: a road map for SMEs. International Journal of Advanced Engineering Technology, Vol. 2 No. 4, 461-464.

Jawadeh, S. 2011. Feasibility of application of six sigma and its role in improving the quality of health services in the government hospitals in Gaza strip from the perspective of senior management. Unpublished Master Thesis, The Islamic University.

Jayaraman, P., Kannabiran, K., Kumar, S.A.V. 2013. A six sigma approach for 
software process improvements and its implementation. International Journal of

Mining, Metallurgy \& Mechanical Engineering (IJMMME), Vol. 1, No. 3, 228-232.

Jovanovic, R., Delic, M., Kamberovic, B., Vulanovic, S., Radlovacki, V. 2013.

Planning the use of lean six sigma as a framework for blood bank management improvements. International Journal of Industrial Engineering and Management (IJIEM), Vol. 4, No. 4, 237-244.

Junankar, A.A., Gupta, P.M., Sayed, A.R., Bhende, N.V. 2014. Six sigma technique for quality improvement in valve industry. IJREAT International Journal of Research in Engineering \& Advanced Technology, Vol. 2, No. 1, 1-5.

Kabir, M., Boby, S., Lutfi, M. 2013. Productivity improvement by using six-sigma. International Journal of Engineering and Technology, Vol. 3, No. 12, 1045-1073.

Kateeb, M. 2009. The Extent unplanned Six Sigma using impact in Housing Bank for trade and finance. Unpublished Master Thesis, Middle East University.

Kaushik, P. 2012. Six Sigma look at in education: a managing perception. International Journal of Research in IT \& Management, Vol. 2, No. 6, 49-59.

Khandekar, A.S., Sulakhe, V.N. 2014. Six sigma - the revival of TQM. International Journal of Medical Engineering and Robotics Researches, Vol. 3. No. 1, 50-58.

Koripadu, M., Subbaiah, K.V. 2014. Problem solving management using six sigma tools \& techniques. International Journal of Scientific \& Technology Research, Vol. 3, No. 2, 91-93.

Kosina, J. 2013. The process to estimate economical benefits of six sigma projects. Quality Innovation Prosperity, Vol. 17, No. 1, 16-27.

Kumar, V.M., Kumar, M.V. 2013. Six sigma approach to quality assurance in global supply chains. International Journal of Science and Research, 2(4), 560-562.

Kumara, V., Khandujaa, R. 2013. Application of six-sigma methodology in SSI: a case Study. International Journal of Current Engineering and Technology, Vol. 3, No. 3, 971-976.

Kumaravadivel, A., Natarajan, U. 2011. Empirical study on employee job satisfaction upon implementing six sigma DMAIC methodology in Indian foundry - a case study. International Journal of Engineering, Science and Technology, Vol. 3, No. 4, pp. 164-184.

Kuptasthien, N., Boonsompong, T. 2011. Reduction of tombstone capacitor problem by six sigma technique: a case study of printed circuit cable assembly line. Proceedings of the 2011 IEEE ICQR, 546-550.

Lancaster, J. 2011. Lean and six sig ma in hospitality organizations: benefits, challenges, and implementation. Unpublished Master thesis, University of Nevada, Las Vegas.

Laureani, A., Antony, J. 2012. Standards for Lean Six Sigma certification. International Journal of Productivity and Performance Management, Vol. 61, No. 1, 110-120.

Maleki, M., Riahi, L., Dashti, T., Karbasian, S. 2013. Reducing waiting time in patients undergone spinal surgeries at operation's room of Shohada-ye-Tajrish hospital using six sigma model. New York Science Journal, Vol. 6, No. 12, 136-141.

Maleyeff, J. 2014. Sustaining public sector lean six sigma: perspectives from North America. Management and Organizational Studies, Vol. 1, No. 2, 92-99.

Vinodh, S., Kumar, S.V., Vimal, K.E.K. 2012. Implementing Lean Sigma in an Indian rotary switches manufacturing organisation. Production Planning \& Control, Vol. 25, No. 4, 288-302. 